\title{
Folate levels in hepatocellular carcinoma patients with portal vein thrombosis
}

\author{
Giulia Malaguarnera ${ }^{1} \mathbb{D}$, Vito Emanuele Catania ${ }^{2 *} \mathbb{D}$, Saverio Latteri ${ }^{2}$, Antonio Maria Borzi ${ }^{3} \mathbb{D}$, Gaetano Bertino $^{4} \mathbb{D}$, \\ Roberto Madeddu ${ }^{5}$ (D), Filippo Drago ${ }^{1}$ a and Michele Malaguarnera ${ }^{3}$ (i)
}

\begin{abstract}
Background: Portal vein thrombosis (PVT) occurs frequently in hepatocellular carcinoma (HCC) and is often diagnosed in the course of a routine patient evaluation and surveillance for liver cancer. The purpose of this study is to investigate the relationship between folate status and portal vein thrombosis.

Methods: HCC with PVT patients were 78, HCC without PVT were 60 and control subjects were 70 randomly selected. We evaluate serum and red blood cellular folate, homocysteine, alpha fetal protein cholesterol, triglycerides, prothrombin time.

Results: HCC patients with PVT showed lower levels of serum folate, respect HCC patients without PVT, with an average difference of $1.6 \mathrm{nmol} / \mathrm{l} p<0.01(95 \% \mathrm{Cl}-2.54$ to -0.66$)$, red cell folate $33.6 \mathrm{nmol} / \mathrm{l} p<0.001(95 \% \mathrm{Cl}-43.64$ to -23.55$)$ and albumin $0.29 \mathrm{~g} / \mathrm{dl} p<0.001$ (95\% Cl -0.42 to -0.15 ); PVT patients displayed higher levels of bilirubin $0.53 \mathrm{mg} / \mathrm{dl} p<0.001$ (95\% Cl 0.23 to 0.78), INR $0.91 p<0.001$ (95\% Cl 0.72 to 1.09), $\gamma \mathrm{GT} 7.9 \mathrm{IU} / \mathrm{I}$ (95\% Cl 4.14 to 11.65) and homocysteine $4.6 \mu \mathrm{mol} / \mathrm{l} p<0.05(95 \% \mathrm{Cl} 0.32$ to 8.87$)$
\end{abstract}

Conclusion: The low folate concentration and higher levels of homocysteine are associated with the loss of antithrombotic function, and with a more aggressive course of HCC and with a higher change of complications related to portal vein thrombosis

Keywords: Folate, Hepatocellular carcinoma, Thrombosis, Portal vein thrombosis, Homocysteine, Red cell folate

\section{Background}

Hepatocellular carcinoma ( $\mathrm{HCC})$ is one of the leading causes of cancer mortality [1].

There are striking variations in its incidence in various parts of the world, although the $83 \%$ of the total deaths occur in developing countries [2,3].

Many studies have focused on the investigation of markers to predict the outcomes of HCC and to exploring accurate prognostic factors for the clinical examination $[4,5]$. Many HCC patients display portal hypertension,

\footnotetext{
*Correspondence: vito.catania@policlinico.unict.tt

${ }^{2}$ Department of Medical, Surgical Sciences and Advanced Technologies

"G.F. Ingrassia", University of Catania, Via Santa Sofia 78, 95123 Catania,

Italy

Full list of author information is available at the end of the article
}

which cause the blood flow velocity of the portal vein to slow down. Changes in haemodynamic of the portal vein are the anatomical base of Portal Vein Thrombosis (PVT) formation. This complication is a multifactorial process, characterized also by the increase of systemic prothrombotic factors and the presence of local inflammatory foci. As a result, there is hypercoagulation, accompanied by the slowing of blood flow and damage to the vessel walls [6-8].

Patients with HCC with PVT have poor prognoses than those without PVT [9-11].

Evidence show a relationship between nutrition and environmental factors in relation to the progression of HCC. For instance, folate (known also as vitamin B9) and its derivatives are found abundantly in leafy green 
vegetable and fresh fruit. These compounds play an essential role in the production and maintenance of new cells and is involved in DNA methylation, DNA synthesis and DNA repair.

Folate is a water-soluble beta-vitamin critical for health. It participates in numerous single-carbon exchange reactions that are essential for the synthesis of nucleotides purine/pyrimidine. Folates have been studied as a potential chemo-preventive agent.

Dietary folate is digested in the jejunal brush border surface by intestinal glutamate carboxy peptidase, followed by the transfer, through the portal vein to the liver where it is transported across membranes by the reduced folate carrier, possibly together with folate binding protein or the proton coupled folate transporter. These molecules are mainly stored in the liver, where are used in several reaction. Then, dietary folate is transported to the systemic blood circulation and in part, eliminated by the biliary excretion [12].

Both dietary and endogenous folate plays an important role in epigenetic methylation reactions, in lipid export, antioxidant defence and the hepatic methionine metabolism, which in turn regulates homocysteine levels $[13,14]$.

The objective of our study is to investigate, the relationship among blood folate and PVT in HCC patients, comparing these variables in controls subjects and in patients with and without PVT.

\section{Methods}

\section{Patients recruitment}

The subject with HCC included in this study were 138 patients with HCC: 78 HCC with PVT (31 females and 47 males) aged 65 or more years, and $60 \mathrm{HCC}$ without PVT (24 female and 36 males), aged 60 or more years, living in Sicily (Italy).

The control subjects were 70 (35 female/35 males), aged 60 years or more. They were randomly selected and healthy without any history of cancer, major organ failure or active intravenous drug abuse.

The inclusion criteria were patients older than 18, with histologically proven HCC and with written informed consent.

This study used similar recruitment strategies, inclusion and exclusion criteria and measurement protocol adopted in previous studies on HCC patients with PVT and in controls subjects.

The questionnaires were administered by trained interview and focused on dietary, sociodemographic, environmental and lifestyle information.

\section{Serum and whole blood folate assay}

Serum and whole blood samples were collected into citrate tubes during the screening visit. They were immediately put on ice and centrifuged $\left(2000 \times g, 4{ }^{\circ} \mathrm{C}, 10 \mathrm{~min}\right)$ within $60 \mathrm{~min}$. Both serum and whole blood samples were stored at $-70{ }^{\circ} \mathrm{C}$ until analysis and were measured using QuantaPhase radioassay II Kit (Bio-Rad Laboratories, Hercules, California).

\section{Statistical analysis}

Data were expressed as mean \pm standard deviation. To assess relationship and differences between folate, Hcy, alfa-fetoprotein of different patent groups, parametric, non-parametric Fisher's exact test and 95\% CI Odds Ratio (O.R.) Baptista-Pike method or ordinary one-way ANOVA with Tukey's multiple comparisons test. A $p$ value $<0.05$ was considered statistically significant. Data were analysed using the GraphPad Prism 8 statistical software package (8.4.2 Macintosh Version; GraphPad Software San Diego, CA).

Univariate and multivariate linear regression were built to assess the relationship between folate concentration and sociodemographic data, area of residence (urban, metropolitan, semi urban, rural), social class (managers, skilled, semiskilled, unskilled) and clinical features of HCC patients.

\section{Results}

PVT patients' ages ranged between 60 years and over; of these $35.90 \%$ were smokers, $12.82 \%$ were diabetics, $12.82 \%$ complained of renal failure; $15.38 \%$ of Hypertension; $23.08 \%$ of cardiovascular disease; $19.23 \%$ of dyspepsia, $12.82 \%$ experienced alcohol consumption. Etiologic factors in PVT patients were $44.87 \%$ for $\mathrm{HCV}, 32.5 \%$ for HBV and $10.26 \%$ unknown (Tables 1 and 2).

HCC without PVT patient's ages ranged 60 years and over; of these $45 \%$ were smokers or previous smokers, $15 \%$ were diabetics, $23.33 \%$ complained of hypertension, $26.67 \%$ of cardiovascular disease, $20 \%$ of renal failure, $35 \%$ of dyspepsia, $26.67 \%$ of alcohol consumption. Etiologic factors were $41.67 \% \mathrm{HCV}, 15 \% \mathrm{HBV}, 16,67 \%$ unknown.

In the control group ages ranged between 60 years and over; of these $28.57 \%$ were smokers, $11.43 \%$ were diabetics, $14.29 \%$ complained of hypertension, $14.29 \%$ of cardiovascular disease, $17.14 \%$ of renal failure, $17.14 \%$ of dyspepsia (Tables 1 and 2).

\section{Comparison from HCC patients with PVT to HCC patients without PVT}

We observed that were lower serum folate $1.6 \mathrm{nmol} / \mathrm{l}$ $p<0.01(95 \% \mathrm{CI}-2.54$ to -0.66$)$, red cell folate 
Table 1 Demographic and baseline characteristics of the study population

\begin{tabular}{|c|c|c|c|c|c|c|c|c|c|}
\hline & \multirow{2}{*}{$\begin{array}{l}\text { With PVT } \\
78 \text { pt }\end{array}$} & \multirow{2}{*}{$\begin{array}{l}\text { NPVT } \\
60 \mathrm{pt}\end{array}$} & \multirow{2}{*}{$\begin{array}{l}\text { Controls } \\
70 \mathrm{pt}\end{array}$} & \multicolumn{2}{|c|}{ PVT versus NPVT } & \multicolumn{2}{|c|}{ PVT versus Control } & \multicolumn{2}{|c|}{ NPVT versus Control } \\
\hline & & & & $p$ value & $95 \% \mathrm{Cl}$ & $p$ value & $95 \% \mathrm{Cl}$ & $p$ value & $95 \% \mathrm{Cl}$ \\
\hline Age (range) & $60-75$ & $60-75$ & $60-75$ & - & - & - & - & - & - \\
\hline Female/male & $31 / 47$ & $24 / 36$ & $35 / 35$ & $>0.9999$ & 0.5042 to 1.968 & 0.2475 & 0.3352 to 1.275 & 0.2913 & 0.3264 to 1.326 \\
\hline $\mathrm{BMI}\left(\mathrm{Kg} / \mathrm{m}^{2}\right)$ & $23.8 \pm 4.4$ & $25.0 \pm 4.2$ & $24.7 \pm 4.2$ & 0.2336 & -2.934 to 0.5336 & 0.409 & -2.562 to 0.7621 & 0.9161 & -1.476 to 2.076 \\
\hline $\begin{array}{l}\text { Systolic blood pres- } \\
\text { sure }(\mathrm{mmHg})\end{array}$ & $140.2 \pm 11.4$ & $137.0 \pm 12.8$ & $140.1 \pm 14.9$ & 0.3293 & -2.097 to 8.497 & 0.9988 & -4.978 to 5.178 & 0.3700 & -8.527 to 2.327 \\
\hline $\begin{array}{l}\text { Diastolic blood pres- } \\
\text { sure }(\mathrm{mmHg})\end{array}$ & $82.2 \pm 8.4$ & $81.8 \pm 9.2$ & $81.4 \pm 9.7$ & 0.9644 & -3.283 to 4.083 & 0.8543 & -2.731 to 4.331 & 0.9661 & -3.373 to 4.173 \\
\hline Heart rate (b.p.m) & $83.7 \pm 9.68$ & $83.8 \pm 9.7$ & $81.4 \pm 10.2$ & 0.9981 & -4.099 to 3.899 & 0.3344 & -1.534 to 6.134 & 0.3517 & -1.697 to 6.497 \\
\hline
\end{tabular}

$\mathrm{Cl}$, confidence interval; pt, patients; bpm, beats per minute; $\mathrm{BMI}$, Body Mass Index

$33.6 \mathrm{nmol} / \mathrm{l} p<0.001$ (95\% CI -43.64 to -23.55 ), albumin $0.29 \mathrm{~g} / \mathrm{dl} p<0.001$ (95\% CI -0.42 to -0.15$)$; were higher bilirubin $0.53 \mathrm{mg} / \mathrm{dl} p<0.001$ (95\% CI 0.23 to 0.78 ), INR $0.91 p<0.001$ (95\% CI 0.72 to 1.09 ), $\gamma \mathrm{GT}$ $7.9 \mathrm{IU} / \mathrm{l}(95 \% \mathrm{CI} 4.14$ to 11.65$)$ and homocysteine $4,6 \mu \mathrm{mol} / \mathrm{l} p<0.05$ (95\% 0.32 to 8.87 ) (Table 3 ).

\section{Comparison between HCC patients with PVT and controls}

We observed that were lower serum folate $3.28 \mathrm{nmol} / \mathrm{l}$ $p<0.001$ (95\% CI -4.20 to -2.31$)$, red cell folate $150 \mathrm{nmol} / \mathrm{l} p<0.001$ (95\% CI -159.53 to -140.46$)$, albumin $0.83 \mathrm{~g} / \mathrm{dl} p<0.001$ (95\% CI -0.96 to -0.65 ); were higher bilirubin $1.63 \mathrm{mg} / \mathrm{dl} p<0.001$ (95\% CI 1.46 to 1.79 ), INR $1.69 p<0.001$ (95\% CI 1.54 to 1.84 ) ALT $16.70 \mathrm{IU} / \mathrm{l}$ $p<0.001$ (95\% CI 13.27 to 20.11) AST 16 IU/l $p<0.001$ (95\% CI 12.62 to 19.58$) \gamma \mathrm{GT} 55.4 \mathrm{IU} / 1 p<0.001$ (95\% CI 51.28 to 58.81 ), $\alpha$ FP $232.9 \mathrm{mg} / \mathrm{l} p<0.001$ (95\% CI 229.16 to 236.63$)$ and homocysteine $22.10 \mu \mathrm{mol} / \mathrm{l} p<0.001$ (95\% CI 51.28 to 58.81 ). The results are showed in Table 3

\section{Comparison between HCC patients without PVT and controls (Table 3 )}

We observed that serum folate was lower $1.66 \mathrm{nmol} / \mathrm{l}$ $p<0.001$ (95\% CI -2.66 to -0.66$)$, red cell folate $116.4 \mathrm{nmol} / \mathrm{l} p<0.001$ (95\% CI -126.14 to -106.66$)$, Albumin $0.52 \mathrm{~g} / \mathrm{dl} p<0.001$ (95\% CI -0.68 to -0.35 ); Bilirubin was higher $1.12 \mathrm{mg} / \mathrm{dl} p<0.001$ (95\% CI 0.86 to 1.38 ), INR $0.78 p<0.001$ (95\% CI 0.61 to 0.94 ) ALT $13.70 \mathrm{IU} / 1 p<0.001$ (95\% CI 9.86 to 17.53 ) AST $15.60 \mathrm{IU} / \mathrm{l}$ $p<0.001$ (95\% CI 11.84 to 19.36 ) $\gamma \mathrm{GT} 47.50 \mathrm{IU} / 1 p<0.001$ (95\% CI 43.52 to 51.47), $\alpha$ FP $237.00 \mathrm{mg} / \mathrm{l} p<0.001(95 \%$ CI 233.64 to 240.36), total homocysteine $17.50 \mu \mathrm{mol} / \mathrm{l}$ $p<0.001$ (95\% CI 13.93 to 21.06).

The median value of serum folate levels was $5.9 \mathrm{nmol} / \mathrm{l}$. Patient were divided into two groups each of 69 patients (Table 4): $\leq 5.9 \mathrm{nmol} / \mathrm{l}$ and $>5.9 \mathrm{nmol} / \mathrm{l}$.

We observed deficient serum folate levels in PVT patients in high grade (IV stage) of HCC $(p=0.028)$ and in presence of extrahepatic metastases $(p=0.016)$ (Table 4).

To identify the prognostic factors of PVT both univariate and multivariate analyses were used to evaluate red cellular folate and other clinical pathological variables.

The results suggested that red cellular folate $(p<0.01)$, higher homocysteine level $(p<0.01)$ and higher AFP $(p<0.05)$ were related to PVT. The other variables included in multivariate models were not statistically significant.

\section{Discussion}

Serum folate, RBC folate and plasma total Hcy are the three most used biochemical indicators to assess folate status [15].

In our study we observed that serum folate and red cells folate in HCC patients with PVT were lower than in no PVT and controls subjects, whereas homocysteine was higher than in no PVT and in control subjects. These conditions induce atherosclerotic and thrombotic vascular disorders and promote oxidative stress, inflammation and endothelial injury, as well prothrombotic effect. Portal vein thrombosis is a relatively frequent event in cirrhosis and HCC, where its incidence varies from 7.4 to $17.8 \%$ in different studies [16-18].

In PVT, the concentration of folate in red cells result as a strong indicator of folate status, because the transitory changes of the diet do not control it. The concentration of folate in red cells is much higher than in plasma. Moreover, its concentration is established during erythropoiesis, for this reason its levels last for approximately 4 months [19].

The patients with PVT and HCC display an aggressive disease course, worsening of liver conditions, complications related to portal hypertension, low tolerance to treatment and lower serum folate and $\mathrm{HHCy}$ if compared with HCC subject without PVT [20-23]. Numerous variables such as agents, drugs, diseases and 


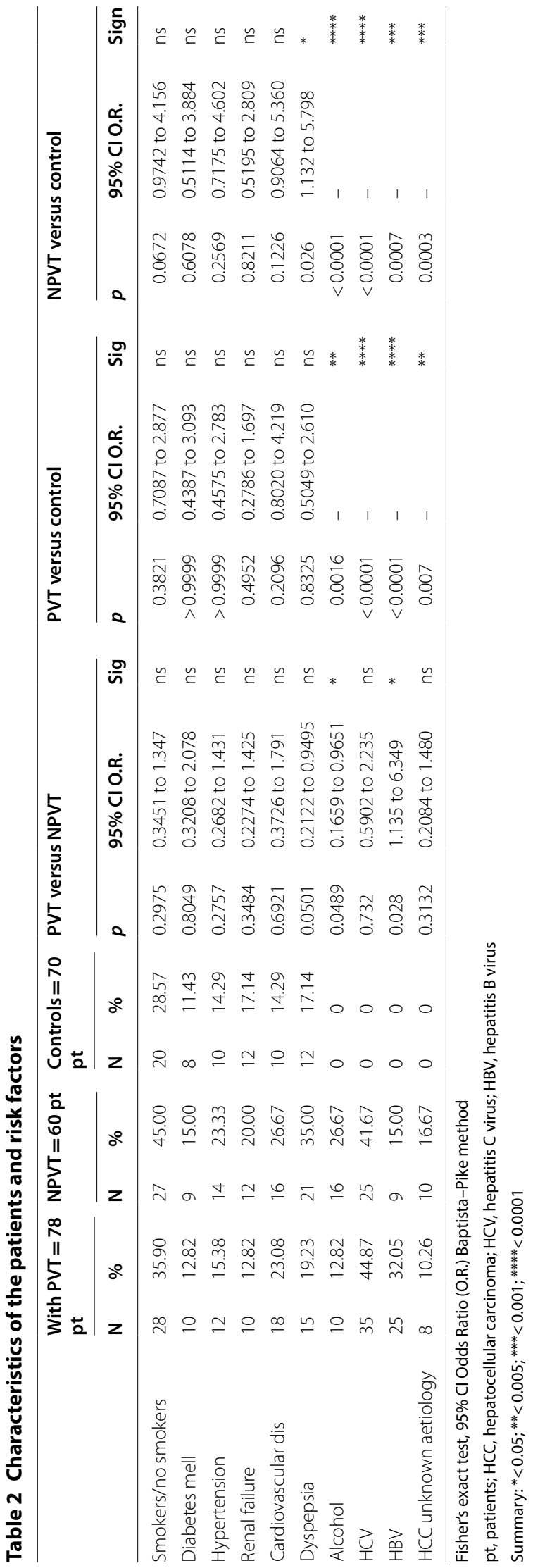


Table 3 Laboratory parameters and classifications of subjects included in the study

\begin{tabular}{|c|c|c|c|c|c|c|}
\hline & PVT $(n=78)$ & NPVT $(n=60)$ & Controls $(n=70)$ & $\begin{array}{l}\text { PVT } \\
\text { versus NPVT( } p \\
\text { value) }\end{array}$ & $\begin{array}{l}\text { PVT } \\
\text { versus Controls } \\
\text { ( } p \text { value) }\end{array}$ & $\begin{array}{l}\text { NPVT } \\
\text { versus Controls } \\
\text { ( } p \text { value) }\end{array}$ \\
\hline Bilirubin (mg/dl) & $2.87 \pm 0.6$ & $2.36 \pm 1.02$ & $1.24 \pm 0.38$ & $<0.001$ & $<0.001$ & $<0.001$ \\
\hline Albumin (g/dl) & $3.15 \pm 0.42$ & $3.44 \pm 0.38$ & $3.96 \pm 0.55$ & $<0.001$ & $<0.001$ & $<0.001$ \\
\hline INR & $2.91 \pm 0.54$ & $2.00 \pm 0.57$ & $1.22 \pm 0.36$ & $<0.001$ & $<0.001$ & $<0.001$ \\
\hline Tot cholesterol (mmol/l) & $5.77 \pm 1.08$ & $5.69 \pm 1.01$ & $5.50 \pm 1.04$ & 0.659 & 0.124 & 0.297 \\
\hline $\mathrm{HDL}(\mathrm{mmol} / \mathrm{l})$ & $1.40 \pm 0.36$ & $1.41 \pm 0.37$ & $1.46 \pm 0.40$ & 0.873 & 0.338 & 0.463 \\
\hline $\mathrm{LDL}(\mathrm{mmol} / \mathrm{l})$ & $3.44 \pm 0.38$ & $3.48 \pm 0.39$ & $3.46 \pm 0.37$ & 0.545 & 0.747 & 0.765 \\
\hline Triglycerides (mmol/l) & $1.57 \pm 0.70$ & $1.50 \pm 0.68$ & $1.48 \pm 0.65$ & 0.556 & 0.421 & 0.864 \\
\hline $\operatorname{ALT}(I \cup / I)$ & $51.20 \pm 10.80$ & $48.20 \pm 11.90$ & $34.50 \pm 10.20$ & 0.124 & $<0.001$ & $<0.001$ \\
\hline AST (IU/I) & $49.20 \pm 10.60$ & $48.70 \pm 10.80$ & $33.10 \pm 10.80$ & 0.786 & $<0.001$ & $<0.001$ \\
\hline$\gamma G T(I U / I)$ & $82.80 \pm 10.20$ & $74.90 \pm 12.10$ & $27.40 \pm 10.80$ & $<0.001$ & $<0.001$ & $<0.001$ \\
\hline $\operatorname{AFP}(\mathrm{mg} / \mathrm{l})$ & $236.10 \pm 15.80$ & $240.20 \pm 14.20$ & $3.20 \pm 0.60$ & 0.117 & $<0.001$ & $<0.001$ \\
\hline Serum folate $(\mathrm{nmol} / \mathrm{l})$ & $5.24 \pm 2.81$ & $6.84 \pm 2.71$ & $8.50 \pm 3.01$ & $<0.001$ & $<0.001$ & 0.001 \\
\hline Red cell folate $(\mathrm{nmol} / \mathrm{l})$ & $144.20 \pm 30.60$ & $177.80 \pm 28.20$ & $294.20 \pm 27.80$ & $<0.001$ & $<0.001$ & $<0.001$ \\
\hline Total homocysteine $(\mu \mathrm{mol} / \mathrm{l})$ & $32.80 \pm 12.20$ & $28.20 \pm 13.10$ & $10.70 \pm 6.90$ & 0.035 & $<0.001$ & $<0.001$ \\
\hline
\end{tabular}

PVT, portal vein thrombosis; INR, International normalized ratio; HDL, high-density lipoprotein; LDL, low-density lipoprotein; ALT, alanine transferase; AST, aspartate transferase, $\gamma \mathrm{GT}$, gamma-glutamil-tranferase

Table 4 Clinical features of the HCC patients

\begin{tabular}{|c|c|c|c|c|c|c|c|c|}
\hline & \multicolumn{4}{|c|}{ Serum folate } & \multirow[t]{3}{*}{$p$ value } & \multirow[t]{3}{*}{ Signif } & \multirow[t]{3}{*}{ Odds-ratio } & \multirow[t]{3}{*}{ 95\% Cl O.R. } \\
\hline & \multicolumn{2}{|c|}{$\leq 5.9 \mathrm{~mm} / \mathrm{l}(69 \mathrm{pt})$} & \multicolumn{2}{|c|}{$>5.9 \mathrm{~mm} / \mathrm{l}(69 \mathrm{pt})$} & & & & \\
\hline & $\mathrm{N}$ & $\%$ & $\mathrm{~N}$ & $\%$ & & & & \\
\hline PVT & 44 & 63.77 & 34 & 49.28 & 0.1219 & ns & 1.812 & 0.9335 to 3.584 \\
\hline HCC stage I & 16 & 23.19 & 20 & 28.99 & 0.5612 & ns & 0.7396 & 0.3337 to 1.573 \\
\hline HCC stage II & 18 & 26.09 & 23 & 33.33 & 0.4564 & ns & 0.7059 & 0.3412 to 1.519 \\
\hline HCC stage III & 20 & 28.99 & 21 & 30.43 & $>0.9999$ & ns & 0.9329 & 0.4610 to 1.876 \\
\hline HCC stage IV & 15 & 21.74 & 5 & 7.25 & 0.0276 & * & 3.556 & 1.265 to 9.289 \\
\hline Clip Score 0-2 & 31 & 44.93 & 28 & 40.58 & 0.7309 & ns & 1.195 & 0.6229 to 2.310 \\
\hline Clip Score 3-6 & 38 & 55.07 & 41 & 59.42 & 0.7309 & ns & 0.8371 & 0.4329 to 1.605 \\
\hline Cirrhosis & 25 & 36.23 & 33 & 47.83 & 0.2272 & ns & 0.6198 & 0.3139 to 1.194 \\
\hline$<50 \mathrm{~mm}$ & 25 & 36.23 & 33 & 47.83 & 0.2272 & ns & 0.6198 & 0.3139 to 1.194 \\
\hline$>50 \mathrm{~mm}$ & 44 & 63.77 & 36 & 52.17 & 0.2272 & ns & 1.613 & 0.8373 to 3.185 \\
\hline Tumour Invasion & 26 & 37.68 & 32 & 46.38 & 0.3886 & ns & 0.6991 & 0.3570 to 1.345 \\
\hline Vascular Invasion & 29 & 42.03 & 31 & 44.93 & 0.8637 & ns & 0.8887 & 0.4619 to 1.701 \\
\hline Extra-hepatic MTS & 44 & 63.77 & 29 & 42.03 & 0.0166 & * & 2.428 & 1.190 to 4.875 \\
\hline
\end{tabular}

PVT, portal vein thrombosis; HCC, hepatocellular carcinoma; Mtd, max tumour diameter

Summary: ${ }^{*}<0.05 ;{ }^{* *}<0.005 ;{ }^{* * *}<0.001 ;{ }^{* * * *}<0.0001$

lifestyle factors have a relevant impact on folate status. Especially those substance that act directly or indirectly on enzymes where folates operate as cofactors, but also as a consequence of the increase of disulphide exchange reactions, or the impairment of folate absorption. In fact, folate deficiency may be caused by the inadequate intake, the reduced absorption from the gastrointestinal tract, or by increased drug consumption and interactions. Subjects without a balanced diet, patients with renal disease, inflammatory bowel disease or malignant disease are more at risk for folate deficiency and, as a consequence, they have elevated levels homocysteine [24-29].

The role of folate deficiency and the hyperhomocysteinemia in PVT and in venous thromboembolism deserve also a relevant attention to evaluate the role of 
these findings in the pre-operative, operative and postoperative thrombotic complication of HCC.

PVT prophylaxis with anticoagulants is still controversial and relatively less investigated; for this reason, it can be recommended on an individual basis. Despite these results, the reduction of thromboembolism with folate supplementation in patients with PVT and HCC is scarce [30-32].

The identification of the high-risk patients with hypofolatemia and/or hyper homocysteinemia, through the evaluation of genetic mutation and nutritional deficiency is essential to plan clinical management in subjects who are candidate for major surgery or liver transplantation [33].

Folate carry out their metabolic functions when it is converted to 5-methyl tetrahydrofolate-. 5-methyltetrahydrofolate and it is associated with improvements in NOS coupling and nitroxide (NO) synthesis in vivo [34-38].

$\mathrm{NO}$ is a potent vasodilator that improves vascular function through its anti-inflammatory, antithrombotic and anti-angiogenic properties.

The study has established an inverse association between the folate level and tumour size, multiplicity and metastases; disease progression was categorized into stages 1 to 4 , and serum folate decreased as disease stage progressed [39-43] (Table 4).

Therefore, folate deficiency aids the incorporation of uracil into DNA, which can lead to DNA breaks and chromosome instability; such breaks could contribute to the increased risk of cancer [44-49].

\section{Conclusion}

Our study supports the hypothesis that the folate status shows a protective role in HCC prevention, development and prognosis.

Further longitudinally designed and interventional studies with a large sample size may help to determine the optimal strategies to improve folate status of $\mathrm{HCC}$ patients [50] and to evaluate the effects in coagulation disorders in HCC patients with PVT [51].

\footnotetext{
Abbreviations

PVT: Portal vein thrombosis; HCC: Hepatocellular carcinoma; $Y G T$ : -Glutamyltransferase; DNA: Deoxyribonucleic acid; aFP: Alpha-fetoprotein; CT: Computed tomography; MR: Magnetic resonance; CLIP: Cancer Liver Italian Program score; TNM: (Tumour Nodes Metastases) Classification of Malignant Tumours; US: Ultrasonography; ${ }^{\circ} \mathrm{C}$ : Degree Celsius; G: Gravitational acceleration; RBC: Red blood cellular folate; tHcy: Total homocysteine; HHcy: Hyperhomocysteine; HCV: Hepatitis C virus; HCB: Hepatitis B virus; INR: International normalized ratio; AST: Aspartate transaminase; ALT: Alanine transaminase; BMI: Body Mass Index; HDL: High-density lipoprotein; LDL: Low-density lipoprotein; NO: Nitroxide.
}

Acknowledgements

Not applicable.

\section{Authors' contributions}

Conceptualization, GM, SL and MM; Data Curation, RM, AMB and VEC; Formal analysis, $A M B, R M$ and VEC; Funding acquisition, GB; Investigation RM, MM, GM, GB and VEC; Project Administration, GB, SL, FD; Supervision, FD; Validation, MM; Visualization, GM and GB; Writing-original draft, MM, GM, SL and VEC; Writing-review and editing, GB, FD, VEC and MM All authors read and approved the final manuscript.

\section{Funding}

This study was funded by internal University funds and partially by the 2016/2018 Department of Research Plan of the University of Catania.

\section{Availability of data and materials}

The datasets used and/or analysed during the current study available from the corresponding author on a reasonable request.

\section{Ethics approval and consent to participate}

The study protocol was approved by the Human Ethics Review Committee of Cannizzaro Hospital and a signed consent form was obtained from each patient. Study recruitment was performed in observation and respect of Helsinki Declaration. All patients gave their written informed consent for the study participation and consent for the publication.

\section{Consent for publication}

Not applicable.

\section{Competing interests}

All authors declare that they have no competing interests.

\section{Author details}

${ }^{1}$ Department of Biomedical and Biotechnological Science, University of Catania, 95123 Catania, Italy. ${ }^{2}$ Department of Medical, Surgical Sciences and Advanced Technologies "G.F. Ingrassia", University of Catania, Via Santa Sofia 78, 95123 Catania, Italy. ${ }^{3}$ Research Centre "The Great Senescence", University of Catania, 95120 Catania, Italy. ${ }^{4}$ Hepatology Unit, Department of Clinical and Experimental Medicine, University of Catania, Policlinico "G. Rodolico", Catania, Italy. ${ }^{5}$ Department of Biomedical Sciences, University of Sassari, Sassari, Italy.

Received: 3 April 2020 Accepted: 2 November 2020 Published online: 10 November 2020

\section{References}

1. Bertino G, Malaguarnera G, Frazzetto E, Sciuto A, Inserra G, Zanghì GN, Malaguarnera M. Responsibility of hepatitis $C$ virus in the development of hepatocellular carcinoma: from molecular alterations to possible solutions. World J Hepatol. 2018;10(6):448-51.

2. Ferlay J, Shin HR, Bray F, Forman D, Mathers C, Parkin DM. Estimates of worldwide burden of cancer in 2008: GLOBOCAN 2008. Int J Cancer. 2010;127(12):2893-917.

3. $\mathrm{KaO} \mathrm{JH}$, Chen DS. Changing disease burden of hepatocellular carcinoma in the Far East and Southeast Asia. Liver Int. 2005;25(4):696-703.

4. Malaguarnera M, Latteri S, Bertino G, Madeddu R, Catania VE, Currò G, Borzì AM, Drago F, Malaguarnera G. D-dimer plasmatic levels as a marker for diagnosis and prognosis of hepatocellular carcinoma patients with portal vein thrombosis. Clin Exp Gastroenterol. 2018;11:373-80.

5. Latteri S, Malaguarnera G, Catania VE, La Greca G, Bertino G, Borzì AM, Drago F, Malaguarnera M. Homocysteine serum levels as prognostic marker of hepatocellular carcinoma with portal vein thrombosis. Curr Mol Med. 2019;19(7):532-8.

6. Galvano F, Malaguarnera M, Vacante M, Motta M, Russo C, Malaguarnera G, D'Orazio N, Malaguarnera L. The physiopathology of lipoprotein (a). Front Biosci (Schol Ed). 2010;2:866-75.

7. Sogaard KK, Astrup LB, Vilstrup H, Gronbaek H. Portal vein thrombosis risk factors, clinical presentation and treatment. BMC Gastroenterol. 2007;7:34. 
8. Malaguarnera G, Gagliano C, Salomone S, et al. Folate status in type 2 diabetic patients with and without retinopathy. Clin Ophthalmol. 2015;9:1437-42

9. Lucock M. Folic acid: nutritional biochemistry, molecular biology, and role in disease processes. Mol Genet Metab. 2000;71(1-2):121-38.

10. Rampersaud GC, Kauwell GP, Hutson AD, Cerda JJ, Bailey LB. Genomic DNA methylation decreases in response to moderate folate depletion in elderly women. Am J Clin Nutr. 2000;72(4):998-1003.

11. Duthie SJ, Narayanan S, Blum S, Pirie L, Brand GM. Folate deficiency in vitro induces uracil misincorporation and DNA hypomethylation and inhibits DNA excision repair in immortalized normal human colon epithelial cells. Nutr Cancer. 2000;37(2):245-51.

12. Kim YI. Folate and colorectal cancer: an evidence-based critical review. Mol Nutr Food Res. 2007;51(3):267-92.

13. Medici $V$, Halsted CH. Folate, alcohol, and liver disease. Mol Nutr Food Res. 2013;57(4):596-606

14. Malaguarnera G, Gagliano C, Giordano M, et al. Homocysteine serum levels in diabetic patients with non proliferative, proliferative and without retinopathy. Biomed Res Int. 2014;2014:191497.

15. Creus M, Deulofeu R, Peñarrubia J, Carmona F, Balasch J. Plasma homocysteine and vitamin B12 serum levels, red blood cell folate concentrations, C677T methylenetetrahydrofolate reductase gene mutation and risk of recurrent miscarriage: a case-control study in Spain. Clin Chem Lab Med. 2013;51(3):693-9.

16. Francoz C, Belghiti J, Vilgrain V, et al. Splanchnic vein thrombosis in candidates for liver transplantation: usefulness of screening and anticoagulation. Gut. 2005;54(5):691-7.

17. Villa E, Cammà C, Marietta M, et al. Enoxaparin prevents portal vein thrombosis and liver decompensation in patients with advanced cirrhosis. Gastroenterology. 2012;143(5):1253-1260.e4.

18. Abdel-Razik A, Mousa N, Elhelaly R, Tawfik A. De-novo portal vein thrombosis in liver cirrhosis: risk factors and correlation with the Model for End-stage Liver Disease scoring system. Eur J Gastroenterol Hepatol. 2015;27(5):585-92.

19. Farrell CJ, Kirsch SH, Herrmann M. Red cell or serum folate: what to do in clinical practice? Clin Chem Lab Med. 2013;51(3):555-69 (Review).

20. den Heijer M, Rosendaal FR, Blom HJ, Gerrits WB, Bos GM. Hyperhomocysteinemia and venous thrombosis: a meta-analysis. Thromb Haemost. 1998;80(6):874-7.

21. Langman LJ, Ray JG, Evrovski J, Yeo E, Cole DE. Hyperhomocyst(e)inemia and the increased risk of venous thromboembolism: more evidence from a case-control study. Arch Intern Med. 2000;160(7):961-4.

22. Obeid R, Hakki T, Jouma M, Herrmann W. The risk of venous thromboembolism associated with the factor $\mathrm{V}$ Leiden mutation and low B-vitamin status. Clin Chem Lab Med. 2003;41(10):1357-62.

23. Quéré I, Perneger TV, Zittoun J, Bellet H, Gris JC, Daurès JP, Schved JF, Mercier E, Laroche JP, Dauzat M, Bounameaux H, Janbon C, de Moerloose $P$. Red blood cell methylfolate and plasma homocysteine as risk factors for venous thromboembolism: a matched case-control study. Lancet. 2002;359(9308):747-52.

24. Mason JB. Biomarkers of nutrient exposure and status in one-carbon (methyl) metabolism. J Nutr. 2003;133 Suppl 3(3):941S-947S.

25. Shane B. Folate status assessment history: implications for measurement of biomarkers in NHANES. Am J Clin Nutr. 2011;94(1):337S-342S. https:// doi.org/10.3945/ajen.111.013367.

26. Durand P, Prost M, Loreau N, Lussier-Cacan S, Blache D. Impaired homocysteine metabolism and atherothrombotic disease. Lab Invest. 2001;81(5):645-72 (review)

27. Stanger $\mathrm{O}$, Weger $\mathrm{M}$, Renner W, Konetschny R. Vascular dysfunction in hyperhomocyst(e)inemia. Implications for atherothrombotic disease. Clin Chem Lab Med. 2001;39(8):725-33 (review)

28. Woo KS, Chook P, Lolin YI, Sanderson JE, Metreweli C, Celermajer DS. Folic acid improves arterial endothelial function in adults with hyperhomocystinemia. J Am Coll Cardiol. 1999;34(7):2002-6.

29. Stanger $\mathrm{O}$, Weger M. Interactions of homocysteine, nitric oxide, folate and radicals in the progressively damaged endothelium. Clin Chem Lab Med. 2003;41(11):1444-54 (review)

30. Walsh KA, Lewis DA, Clifford TM, et al. Risk factors for venous thromboembolism in patients with chronic liver disease. Ann Pharmacother 2013;47(3):333-9.
31. Khoury T, Ayman AR, Cohen J, Daher S, Shmuel C, Mizrahi M. The complex role of anticoagulation in cirrhosis: an updated review of where we are and where we are going. Digestion. 2016;93(2):149-59.

32. Vivarelli M, Zanello M, Zanfi C, et al. Prophylaxis for venous thromboembolism after resection of hepatocellular carcinoma on cirrhosis: is it necessary? World J Gastroenterol. 2010;16(17):2146-50.

33. Amitrano L, Brancaccio V, Guardascione MA, et al. Inherited coagulation disorders in cirrhotic patients with portal vein thrombosis. Hepatology. 2000;31(2):345-8.

34. Stanhewicz AE, Alexander LM, Kenney WL. Folic acid supplementation improves microvascular function in older adults through nitric oxidedependent mechanisms. Clin Sci (Lond). 2015;129(2):159-67. https://doi. org/10.1042/CS20140821.

35. Antoniades C, Antonopoulos AS, Tousoulis D, Marinou K, Stefanadis C. Homocysteine and coronary atherosclerosis: from folate fortification to the recent clinical trials. Eur Heart J. 2009;30(1):6-15. https://doi. org/10.1093/eurheartj/ehn515.

36. Antoniades C, Shirodaria C, Leeson P, Baarholm OA, Van-Assche T, Cunnington C, Pillai R, Ratnatunga C, Tousoulis D, Stefanadis C, Refsum H, Channon KM. MTHFR 677 C>T Polymorphism reveals functional importance for 5-methyltetrahydrofolate, not homocysteine, in regulation of vascular redox state and endothelial function in human atherosclerosis. Circulation. 2009;119(18):2507-15. https://doi.org/10.1161/CIRCULATIO NAHA.108.808675.

37. Antoniades $C$, Tousoulis D, Stefanadis C. Nitric oxide-releasing aspirin: will it say NO to atherothrombosis? Int J Cardiol. 2007a;118(2):170-2. https:// doi.org/10.1016/j.ijcard.2006.08.002.

38. Antoniades C, Tousoulis D, Stefanadis C. Effects of endothelial nitric oxide synthase gene polymorphisms on oxidative stress, inflammatory status, and coronary atherosclerosis: an example of a transient phenotype. J Am Coll Cardiol. 2007b;49(11):1226. https://doi.org/10.1016/j.jacc.2006.12.029 (author reply 1226-7).

39. Ogren M, Bergqvist D, Björck M, Acosta S, Eriksson H, Sternby NH. Portal vein thrombosis: prevalence, patient characteristics and lifetime risk: a population study based on 23,796 consecutive autopsies. World J Gastroenterol. 2006;12(13):2115-9.

40. Ho CT, Shang HS, Chang JB, Liu JJ, Liu TZ. Folate deficiency-triggered redox pathways confer drug resistance in hepatocellular carcinoma. Oncotarget. 2015;6(28):26104-18.

41. Welzel TM, Katki HA, Sakoda LC, Evans AA, London WT, Chen G, O'Broin S, Shen FM, Lin WY, McGlynn KA. Blood folate levels and risk of liver damage and hepatocellular carcinoma in a prospective high-risk cohort. Cancer Epidemiol Biomarkers Prev. 2007;16(6):1279-82.

42. Choi SW, Mason JB. Folate status: effects on pathways of colorectal carcinogenesis. J Nutr. 2002;132(8 Suppl):2413S-2418S (review).

43. Goll MG, Bestor TH. Eukaryotic cytosine methyltransferases. Annu Rev Biochem. 2005;74:481-514 (review)

44. Malaguarnera G, Latteri S, Madeddu R, et al. High carbohydrate 19-9 antigen serum levels in patients with nonmelanoma skin cancer and primary occult cancer. Biomedicines. 2020;8(8):E265.

45. Quirk M, Kim YH, Saab S, Lee EW. Management of hepatocellular carcinoma with portal vein thrombosis. World J Gastroenterol. 2015:21(12):3462-71.

46. Chan SL, Chong CC, Chan AW, Poon DM, Chok KS. Management of hepatocellular carcinoma with portal vein tumor thrombosis: review and update at 2016. World J Gastroenterol. 2016;22(32):7289-300.

47. Bruix J, Sherman M. American Association for the Study of Liver Diseases. Management of hepatocellular carcinoma: an update. Hepatology. 2011;53(3):1020-2.

48. Omata M, Lesmana LA, Tateishi R, Chen PJ, Lin SM, Yoshida H, Kudo M, Lee JM, Choi BI, Poon RT, Shiina S, Cheng AL, Jia JD, Obi S, Han KH, Jafri W, Chow P, Lim SG, Chawla YK, Budihusodo U, Gani RA, Lesmana CR, Putranto TA, Liaw YF, Sarin SK. Asian Pacific Association for the Study of the Liver consensus recommendations on hepatocellular carcinoma. Hepatol Int. 2010;4(2):439-74

49. Kuo CS, Lin CY, Wu MY, Lu CL, Huang RF. Relationship between folate status and tumour progression in patients with hepatocellular carcinoma. Br J Nutr. 2008;100(3):596-602.

50. Malaguarnera M, Catania VE, Borzì AM, Malaguarnera S, Madeddu $\mathrm{R}$, Bertino $\mathrm{G}$, Latteri S. Blood homocysteine levels are increased in 
hepatocellular carcinoma patients with portal vein thrombosis. A single center retrospective cohort study. Int J Surg Open. 2018;15:60-5.

51. Jacob RA, Gretz DM, Taylor PC, et al. Moderate folate depletion increases plasma homocysteine and decreases lymphocyte DNA methylation in postmenopausal women. J Nutr. 1998;128(7):1204-12.

\section{Publisher's Note}

Springer Nature remains neutral with regard to jurisdictional claims in published maps and institutional affiliations.
Ready to submit your research? Choose BMC and benefit from:

- fast, convenient online submission

- thorough peer review by experienced researchers in your field

- rapid publication on acceptance

- support for research data, including large and complex data types

- gold Open Access which fosters wider collaboration and increased citations

- maximum visibility for your research: over $100 \mathrm{M}$ website views per year

At BMC, research is always in progress.

Learn more biomedcentral.com/submissions 